\title{
International perspectives on the implementation of reproductive carrier screening
}

Martin B Delatycki ${ }^{1,2,3}$, Fowzan Alkuraya ${ }^{4,5,6}$, Alison Archibald ${ }^{1,2,3}$, Carlo Castellani ${ }^{7}$, Martina Cornel $^{8,9}$, Wayne W Grody ${ }^{10,11}$, Lidewij Henneman ${ }^{8,9}$, Adonis Ioannides ${ }^{12}$, Edwin Kirk $^{13,14,15}$, Nigel Laing ${ }^{16,17}$, Anneke Lucassen ${ }^{18}$, John Massie ${ }^{2,3,19}$, Juliette Schuurmans ${ }^{18,20}$, Meow-Keong Thong ${ }^{21}$, Irene van Langen ${ }^{20}$, Joël Zlotogora ${ }^{22}$

${ }^{1}$ Victorian Clinical Genetics Services, Parkville, Victoria, Australia

${ }^{2}$ Murdoch Children's Research Institute, Parkville, Victoria, Australia

${ }^{3}$ Department of Paediatrics, University of Melbourne, Parkville, Victoria, Australia

${ }^{4}$ Department of Genetics, King Faisal Specialist Hospital and Research Centre, Riyadh,

Saudi Arabia

${ }^{5}$ Saudi Human Genome Program, King Abdulaziz City for Science and Technology, Riyadh, Saudi Arabia

${ }^{6}$ College of Medicine, Alfaisal University, Riyadh, Saudi Arabia

${ }^{7}$ IRCCS Istituto Giannina Gaslini, Cystic Fibrosis Centre, Genoa, Italy

${ }^{8}$ Amsterdam UMC, Vrije Universiteit Amsterdam, Department of Clinical Genetics, Amsterdam, The Netherlands

${ }^{9}$ Amsterdam Reproduction and Development Research Institute, Amsterdam, The Netherlands

${ }^{10}$ Divisions of Medical Genetics and Molecular Diagnostics, Departments of Pathology and

Laboratory Medicine, Pediatrics, and Human Genetics, UCLA School of Medicine, Los This is the author manuscript accepted for publication and has undergone full peer review but

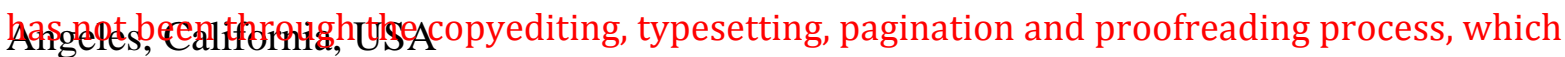
may lead to differences between this version and the Version of Record. Please cite this article as doi: $10.1002 / \mathrm{pd} .5611$

This article is protected by copyright. All rights reserved. 
${ }^{11}$ UCLA Institute for Society and Genetics, Molecular Diagnostic Laboratories and Clinical Genomics Center, UCLA Medical Center, Los Angeles, California, USA

${ }^{12}$ Clinical Genetics, University of Nicosia Medical School, Nicosia, Cyprus

${ }^{13}$ Sydney Children's Hospital, Randwick, New South Wales, Australia

${ }^{14}$ New South Wales Health Pathology, Randwick, New South Wales, Australia

${ }^{15}$ School of Women's and Children's Health, University of New South Wales, Randwick, New South Wales, Australia

${ }^{16}$ University of Western Australia Centre for Medical Research and Harry Perkins Institute of Medical Research, QEII Medical Centre, Nedlands, Western Australia, Australia.

${ }^{17}$ Neurogenetic Unit, Department of Diagnostic Genomics, PathWest Laboratory Medicine, QEII Medical Centre, Nedlands, Western Australia, Australia.

18 Faculty of Medicine, Southampton Medical School, University of Southampton, Southampton, UK

19 Department of Respiratory Medicine, Royal Children's Hospital, Parkville, Victoria, Australia

${ }^{20}$ University of Groningen, University Medical Center Groningen, Department of Genetics, Groningen, The Netherlands

${ }^{21}$ Genetics and Metabolism Unit, Department of Paediatrics, Faculty of Medicine, University of Malaya, Kuala Lumpur, Malaysia

${ }^{22}$ Hadassah-Hebrew University Medical School, Jerusalem, Israel

Running head: Global reproductive carrier screening

Correspondence to:

Professor Martin Delatycki

This article is protected by copyright. All rights reserved. 
Victorian Clinical Genetics Services

Royal Children's Hospital

Flemington Road

Parkville 3052

Victoria Australia

Ph: +61383416290

Fax: +61383416385

Email: martin.delatycki@vcgs.org.au

The authors have no conflicts of interest

What's already known about this topic?

- Reproductive carrier screening is available for an ever increasing number of autosomal recessive and X-linked recessive disorders.

- Reproductive carrier screening takes place in different ways in different jurisdictions with some Government funding and some user-pays.

What does this study add?

- This review identifies many different approaches to reproductive carrier screening in different countries.

- This largely relates to geographical variation in carrier frequencies of genetic conditions and local healthcare, financial, cultural and religious factors.

Word cound- 4812

Tables- 1

This article is protected by copyright. All rights reserved. 
Figures- 0

This article is protected by copyright. All rights reserved. 


\section{Abstract}

Reproductive carrier screening started in some countries in the 1970s for hemoglobinopathies and Tay-Sachs disease. Cystic fibrosis carrier screening became possible in the late 1980s and with technical advances, screening of an ever increasing number of genes has become possible. The goal of carrier screening is to inform people about their risk of having children with autosomal recessive and $\mathrm{X}$-linked recessive disorders, to allow for informed decision making about reproductive options. The consequence may be a decrease in the birth prevalence of these conditions, which has occurred in several countries for some conditions. Different programs target different groups (high school, premarital, couples before conception, couples attending fertility clinics, pregnant women) as does the governance structure (public health initiative, user pays). Ancestry based offers of screening are being replaced by expanded carrier screening panels with multiple genes that is independent of ancestry. This review describes screening in Australia, Cyprus, Israel, Italy, Malaysia, Netherlands, Saudi Arabia, United Kingdom and United States of America. It provides an insight into the enormous variability in how reproductive carrier screening is offered across the globe. This largely relates to geographical variation in carrier frequencies of genetic conditions and local healthcare, financial, cultural and religious factors. 


\section{Introduction}

Reproductive carrier screening (RCS) is the process of testing individuals and couples for their risk of having children with autosomal recessive and X-linked recessive conditions. ${ }^{1}$ Such screening can be done prior to pregnancy or in the early stages of pregnancy. It can be offered to individuals prior to forming a relationship such as through high school screening programs, to individuals prior to an arranged marriage such as through the Dor Yeshorim program and to couples prior to becoming pregnant or in early pregnancy. ${ }^{2}$ When both members of a couple are carriers of an autosomal recessive condition or a woman is a carrier an X-linked condition there is an increased chance (generally 1 in 4 ) of having an affected child. Couples with an increased risk have a number of reproductive options to avoid or prepare for having a child with that condition depending on their choices. These include testing a pregnancy with the option of terminating those that are affected by the genetic condition or testing embryos produced by IVF (preimplantation genetic testing for monogenic disorders, PGT-M). RCS provides people at increased risk of having a child with a genetic condition with reproductive autonomy in relation to whether or not to take steps to avoid having a child with that condition.

Reproductive carrier screening became possible in the 1970s. This preceded the ability to test directly for genetic mutations by more than a decade. Carriers of some conditions have differences in blood test parameters that allow them to be identified as heterozygotes. ${ }^{3}$ This includes hemoglobinopathies such as beta-thalassemia and sickle cell disease. Carriers of these disorders have reduced mean corpuscular volume (MCV) and changes in hemoglobin electrophoresis indices. It was also possible to screen for Tay-Sachs disease (TSD), a lethal neurodegenerative condition. ${ }^{4}$ TSD is caused by mutations in the gene that encodes the 
hexosaminidase A enzyme (HEXA). Carriers of TSD almost always have lower levels of hexosaminidase A than non-carriers.

In the late 1980s it became possible to identify carriers by genetic testing. Cystic fibrosis (CF) screening was among the first conditions for which screening was offered by genetic testing $^{5}$ following identification of mutations in CFTR as the cause. In addition, some TSD programs changed from enzymatic testing to molecular testing which has the advantage of being a less complex assay that does not require a blood sample. ${ }^{6}$ From there, screening for an increasing number of autosomal recessive and $\mathrm{X}$-linked recessive conditions has become possible.

Initially, screening focused on ethnic groups at higher risk of specific genetic disorders. For example screening for hemoglobinopathies was commonly offered to those from Mediterranean regions, Africa and Asia. TSD screening programs were introduced in Ashkenazi Jewish communities and CF screening was increasingly offered to those of European descent.

With the advent of massively parallel sequencing (also called next-generation sequencing), carrier screening has become possible for hundreds of conditions relatively cheaply. ${ }^{7}$ This makes carrier screening more attractive than single gene mutation testing of the past. The new screening technology is referred to as expanded carrier screening (ECS). ECS removes the need for ethinic specific gene mutation panels which in the past raised concerns about discimination. ${ }^{8}$ Such screening also required the individual and health professional to recognise the ethnicity of that person which is sometimes complex. ${ }^{9}$ One concern about ECS 
that has been raised is in relation to the ability of people to provide informed consent for testing for multiple conditions. ${ }^{10}$

RCS has been adopted in various centres and/or countries, often in an ad hoc manner. In most jurisdictions it is available to those able to pay with relatively few national funded programs. In this review we provide information about the current screening programs in nine countries/regions. It is not possible to include all countries in such a review but we have attempted to draw together experiences from across the world highlighting considerations arising from differing healthcare systems, cultures and religions. ${ }^{11}$ We have included countries from multiple regions and counties where carrier screening has been conducted in different ways to address local challenges such as those posed by funding constraints and religious requirements. A summary of RCS in these nine countries/regions and the availability of reproductive options is presented in Table 1 .

As this is a review article, no approval from a Human Research Ethics Committee was required. Similarly there are no original data presented in this review so data sharing is not relevant to this article. 


\section{Australia}

In Australia, reproductive carrier screening began in an ad hoc way in the 1970s with hemoglobinopathy screening. ${ }^{12}$ Post World War 2 migration from Mediterranean countries meant the number of carriers of beta-thalassemia increased in the Australian population, which had hitherto been predominantly indigenous and Northern European. From the late 1970s migration from South East Asia increased the number of alpha-thalassemia carriers. Hemoglobinopathy screening was initially inconsistent, since it relied on red blood cell parameter testing. Nevertheless, the live birth prevalence of thalassemia dropped substantially after introduction of screening. ${ }^{13}$ Screening for hemoglobinopathy carrier status is Government funded.

Systematic TSD screening began in Jewish high schools (offered to those in the penultimate year of school), and communities more generally, in Sydney (1995) ${ }^{14}$ and Melbourne (1997). ${ }^{15}$ The high school program initially incurred a cost and testing was from a blood sample. From 1998 testing was free with collection by cheek swab, the combination increasing participation to $96 \% .^{6}$ In 2008 , the program was increased to include seven conditions (TSD, CF, Canavan disease, Bloom syndrome, Nieman Pick disease type A, Fanconi anaemia and familial dysautonomia). ${ }^{16}$ The Melbourne program ceased in 2016 since it was considered that by the time most students will be planning a family, much broader screening will be available than the screening that was being offered. ${ }^{2}$

CF carrier screening in people with no family history of the disorder began in Victoria in 2006 with screening offered pre and in the early stages of pregnancy, largely by obstetricians and general practitioners (GPs). ${ }^{17}$ Up until that point, only prospective parents with a family 
history of CF could access testing. The initial CF carrier screening program was developed on a fee-for-service basis using a cheek swab mailed to the testing laboratory and by 2010 there were approximately 3000 screening tests per year (birth rate in Victoria about 80,000/year). ${ }^{18}$ From 2012, the program was expanded to include spinal muscular atrophy (SMA) and fragile X syndrome (FXS) with around 1 in 20 women screened being a carrier of at least one of the conditions. ${ }^{19}$

From 2014 the opportunity for ECS became possible through private providers. In 2019 the Royal Australian and New Zealand College of Obstetricians and Gynaecologists published guidelines recommending that at a minimum, information on carrier screening for hemoglobinopathies, CF, SMA and FXS be offered to women preconception or in the first trimester with consideration given to offering ECS. ${ }^{20}$ Between 2019-2021 there will be a Government funded trial of reproductive carrier screening for $>1000$ genes in 10,000 couples Australia-wide. ${ }^{2}$ Genes were selected based on the severity of conditions. The aim of this research project is to test the feasibility of a National, Government-funded reproductive carrier screening program.

Genetic counseling, prenatal diagnosis and pregnancy termination is Government funded and is free of charge to couples found to have an increased risk of having a child with one of the conditions for which screening is done. Whilst there is some Government funding for IVF, PGT-M currently incurs considerable out of pocket expenses in Australia. 


\section{Cyprus}

The carrier rate for beta-thalassemia mutations in Cyprus is about 1 in 8 and is one of the highest in the world. ${ }^{21}$ It is hypothesized that this reflects the survival advantage of thalassemia carriers for malaria, which was once endemic on the island. By the late 1960s, beta-thalassemia major was established as a major public health challenge in Cyprus. Affected individuals faced a debilitating disease associated with significant morbidity and mortality. On the other hand, the management of beta-thalassemia included regular blood transfusions and the use of iron chelation therapy, that resulted in increasing strain on national healthcare resources.

In the early 1970s, the Government commissioned a report on the projected impact of betathalassemia on healthcare delivery in Cyprus. ${ }^{22}$ Following that report, the first population screening program in Cyprus for beta-thalassemia carriers was launched in 1973 based on a combination of hemoglobin electrophoresis and the assessment of hematological indices. The campaign focused primarily on high school students and army conscripts, as well as relatives of affected individuals. ${ }^{23}$ By 1977, prenatal diagnosis could be offered ${ }^{24}$ and screening shifted to prospective parents before or during pregnancy. By the early 1980 s, there was a drive towards a more effective screening method for individuals of reproductive age leading to the introduction of the premarital certificate. In essence, couples seeking to marry through the Greek Orthodox Church were asked by Church authorities to present evidence that they had been screened and received relevant counseling at the National Thalassaemia Centre. Although this screening approach was not mandatory, the uptake was very high and the choice of prenatal diagnosis and termination of affected pregnancies resulted in a dramatic reduction in the birth prevalence of beta-thalassemia. ${ }^{25-27}$ 
Over the years, state authorities have played a more prominent role in informing couples about screening, in view of an increasing number of civil marriages. Initial post-test counseling takes place at the specialist National Centre and this also covers alpha-thalassemia and sickle cell disease. Prospective parents may consider the options of PGT-M or prenatal diagnosis and genetic testing.

In addition to hemoglobinopathy screening, a national screening programme for the prevention of Friedreich ataxia has been running since $2011 .{ }^{28}$ It is offered to individuals of child bearing age who originate from the Paphos district of Cyprus and is based on the high frequency of carriers in this section of the population which is estimated to be about 1 in $11 .^{29}$ Referrals are made by primary care doctors or obstetricians and testing is for the common GAA repeat expansion in intron 1 of the $F X N$ gene. 


\section{Israel}

A carrier-screening program among Ashkenazi Jews to detect couples at risk for having children with TSD was organized and funded by the Israeli Ministry of Health in $1980 .^{30}$ Later, a betathalassemia carrier screening program was implemented among Arabs, Druze and Jewish communities. Since then, the carrier-screening program has been under the aegis of the Ministry of Health and has gradually expanded. ${ }^{31}$ In 2002 , the first expansion was to include severe diseases with a frequency of 1 in 1000 or higher, targeted to local Arab and Druze communities (villages/tribes). In 2008 the national program was further expanded to include familial dysautonomia for Ashkenazi Jews and CF for the whole population. Since January 2013, the program includes carrier screening for all common severe diseases as recommended by the Association of Israeli Medical Geneticists (carrier frequency $>1$ in 60 and/or disease frequency $>1$ in 15:000 live births) and is updated yearly. The carrier-screening program includes CF, SMA and FXS for the whole population and additional diseases according to the ethnicity of the couple. These additional carrier-screening tests are performed among Jews according to the community of origin and among Arabs and Druze according to the religion and the locality of origin or tribe among the Bedouins of the Negev. In 2013, where 171,444 babies were born in Israel, there were approximately 62,000 individuals screened in the national program. ${ }^{31}$

The recommended tests are free of charge for all the Israeli citizens and are performed either in genetic units, in the community or through the Dor Yeshorim program. ${ }^{32}$ The Dor Yeshorim program is designed specifically for ultra-orthodox Jews, where a couple have screening prior to an arranged marriage which goes ahead if both members of the couple are not carriers of the same recessive condition. In the general population, the recommendations and explanations before the tests are given by genetic counselors or medical personnel under the supervision of a 
medical geneticist. The information includes the option to perform additional patient funded tests for less frequent or less severe diseases. Most often, the woman is tested first and if found to be a carrier her partner is tested. At-risk couples receive genetic counseling and may access prenatal diagnosis or PGT-M free of charge.

This article is protected by copyright. All rights reserved. 


\section{Italy}

In Italy the history of carrier screening has mainly concerned thalassemia and CF. Neither has been implemented at the national level and both originated from regional health strategies. A structured policy for carrier detection was developed in areas where thalassemia is highly prevalent, like Sardinia, Sicily and the Po river delta. ${ }^{33} \mathrm{CF}$ is homogeneously distributed throughout Italy, but carrier screening has been more extensively offered and used in northeastern Italy, following work by the University of Padua. ${ }^{34}$ It is supported by the regional health system.

The first experiences in thalassemia carrier screening date back to the 1970 s, when nongenetic tests were offered in high schools and, later, to young couples. These campaigns were well received by the local populations, who were generally aware of the prevalence and severity of the condition. Identification of carrier couples led to a dramatic reduction in the birth of affected children. ${ }^{33}$ Today the test is mainly offered by obstetricians and GPs and the live-birth prevalence remains low, with a stable number of carrier couples accepting the risk of having affected children, possibly because of the better treatments available compared to the past such as oral iron chelation therapy. ${ }^{33}$

Since 1993 CF carrier screening has been widely practiced in part of north- eastern Italy, although not in a formal setting. The test is usually offered by obstetricians and primary care physicians and performed in public or private laboratories. In 25 years more than 200,000 tests have been performed and more than 7,000 heterozygotes have been identified. 
In the initial twenty years of $\mathrm{CF}$ carrier screening the live-birth prevalence decreased dramatically. ${ }^{35,36}$ However, since 2011 the number of carrier screening tests for CF has substantially decreased, likely a reflection of changes to local regulations for the test offer and reimbursement. There has been a concomitant increase in $\mathrm{CF}$ incidence, ${ }^{37}$ confirming the inverse correlation between RCS and number of children born with CF.

The attitudes of the general population and health professionals towards CF carrier screening were investigated by two studies supported by the Italian Cystic Fibrosis Research Foundation. Three citizen juries, a method of deliberative democracy to engage citizens in health decision making, were in favour of screening. In addition, an online public consultation found that the general public (86\%) and health workers $(63 \%)$ believe that the National Health Service should provide CF RCS. ${ }^{38,39}$ 


\section{Malaysia (and other South East Asian countries)}

The most common genetic diseases in Malaysia are alpha and beta thalassemia and glucose6-phosphate dehydrogenase (G6PD) deficiency where 1 in 15 and 1 in 29 of the population are carriers of each of these conditions respectively. ${ }^{40,41}$ There is newborn screening for G6PD and it has a good outcome if it is treated early. The molecular epidemiology of thalassemia is well characterized in the major urban areas although there are certain indigenous populations who have not been well studied. ${ }^{42}$ In addition, thanks to expanded newborn screening using tandem mass spectrometry, the epidemiology of inborn errors of metabolism (IEM) showed that while phenylketonuria, medium chain acyl CoA dehydrogenase (MCAD) deficiency and galactosaemia occur in Malaysia, they are relatively less common than other IEMs such as citrin deficiency and organic acidemias. ${ }^{43}$

Prenatal diagnosis is available and termination of pregnancy is legal in Malaysia when the mother's health is at risk, but it may not be available due to the high cost as well as cultural, religious and other factors. ${ }^{44}$ Instead of screening in early pregnancy, alternative population screening strategies are offered. For example, thalassemia screening is offered to high school students aged 15-16 years of age. ${ }^{41}$ In Malaysia, Singapore, Thailand and other countries, hematological indices are used to screen for thalassemia in cascade and premarital screening programs. $^{45}$ Experience from population carrier screening for a single disease such as thalassemia in Guangxi, China resulted in the reduction of birth of children with severe thalassemia from $2.5 \%$ (2009) to $0.6 \%$ (2017). ${ }^{46}$ Expanding carrier screening from a single disorder to 11 monogenic diseases using next generation sequencing in 10,476 couples in China, showed that $27.5 \%$ of individuals without self-reported family history of disorders, were found to be carriers of at least one of the 11 conditions. ${ }^{47}$ Shen and colleagues cautioned 
that $94 \%$ of hypothetical East Asian fetuses affected by a genetic condition would be missed if screening only occurs for conditions in recommended guidelines. ${ }^{46}$ It was instructive to note that a carrier prevalence study of 104 genes for 80 treatable inherited disorders in Singapore showed $6 \%$ of a cohort of 831 were carriers of 1 of 13 treatable inherited disorders with citrin deficiency and Wilson disease having the highest carrier frequencies. ${ }^{48}$ This suggests that population-specific genomics data are needed before targeted RCS can be implemented in Asia.

Finally, genetic counseling is essential in supporting RCS. In Malaysia and many parts of South East Asia, genetics services are not widely available and there is lack of healthcare resources and allocation for RCS. Hence it is expected that RCS will be largely undertaken on a user-pays basis. In view of the above challenges, RCS will require further support and information before it can be implemented in Malaysia and many other parts of South East Asia. 


\section{Netherlands}

In the Netherlands hemoglobinopathy screening first appeared in the 1970 's. ${ }^{49}$ At that time, in collaboration with the Dutch Caribbean island of Curacao, a pediatrics professor started scientific research on hemoglobinopathies in the northern city of Groningen. Meanwhile in Amsterdam, where more migrants lived, screening was offered to individuals at high risk attending the tropical medicine clinic.Ethnicity surfaced as the impeding factor. In the 1990's hemoglobinopathy screening was found to be "not opportune" due to low prevalence, lack of knowledge and fear of stigmatization. ${ }^{49}$ Some primary care midwives offer hemoglobinopathy screening on an ad hoc basis. ${ }^{50}$

The first pilot study on preconception CF carrier couple screening started in 1997 in the midwestern region of the Netherlands, where individuals aged 20-35 years were invited to participate. ${ }^{51}$ Invitation letters were sent by a Municipal Health Service or GP. Couples could visit an educational group session or go to their GP. The highest response rate was found for GP consultation (25\%). The main reason for non-response was "lack of time to attend". In 2005 a combined offer of hemoglobinopathy and CF carrier screening based on ethnicity was sent to 9,453 individuals (20-35 years), including 50-60\% non-Western immigrants, in eight districts of Amsterdam, out of whom 72 couples participated. ${ }^{52}$ In 2010 CF carrier screening was offered direct-to-consumer via a hospital website. The offer ended after six years because of the low uptake and the fact that it was not primarily used by people without a family history of $\mathrm{CF}^{53}$

In a genetically isolated population (village) in the northwest of the Netherlands, preconception carrier screening for five conditions more common in that community has been 
offered since $2012 .^{54}$ Due to religious and social factors, most children are born to couples where both members are from the village. Prospective parents are at relatively high risk of having a child with one of five severe childhood disorders compared to the general population. The screening tests are offered through an outpatient clinic in collaboration with the local midwifery practice.

In the Netherlands, there are no private providers offering carrier testing. ECS has been made available to interested couples by Amsterdam University Medical Centers since 2016 and this covers 50 diseases. Interested couples register on the website for face-to-face genetic counseling. For some couples with higher a priori risk (e.g. Ashkenazi Jewish origin, consanguineous couples) genetic counseling and testing are partly reimbursed by healthinsurance.

ECS was offered in an implementation pilot study in the Northern Netherlands in $2016 .^{55}$ Because research showed that health professionals and the public prefer testing by GPs, ${ }^{56}$ this was the way the pre-test counseling and test were offered. Trained GPs from nine practices invited 4,295 female patients aged 18-40 to take part in free couple-based ECS. The pilot demonstrated that $14 \%$ of eligible couples accepted ECS offered by their GP and that this screening is feasible and does not lead to unacceptable anxiety. Currently those GPs are still offering this test to their patients on a fee-for service basis. . 


\section{Saudi Arabia}

Saudi Arabia is the largest Middle Eastern country, with a population of nearly 30 million, almost two thirds of whom are Saudi citizens. Consanguinity among Saudi parents exceeds $50 \%$. This, combined with nearly half a million births per year, translates into a vast number of infants affected by autosomal recessive conditions. ${ }^{57}$ Saudi Arabia has the highest documented number of autosomal recessive disorders per capita, in the world. ${ }^{57}$

The power of consanguinity loops to render both ancient (founder) and young deleterious recessive alleles homozygous cannot be overemphasized. Until recently, public health preventative strategies have focused solely on the perceived predominance of hemoglobinopathies (sickle cell disease and thalassemia). There has been a premarital screening program that has been in effect since 2004 but is limited to sickle cell disease and thalassemia.

Recent advances made possible by NGS has brought many other disorders to the spotlight. In Saudi Arabia, autosomal recessive causes of intellectual disability have been shown to be the single most common class of recessive diseases and these can be caused by both private and founder mutations. ${ }^{58}$ Previous work, including a large study involving $>2,200$ families with phenotypes that represent the entire Mendelian landscape, has shown that founder mutations account for at least $40 \%$ of the mutation pool. ${ }^{59}$

With thousands of such founder variants identified to date, and with the capacity to screen for them in a single genotyping assay relatively inexpensively, the time is now ripe for implementing a population-wide premarital screening program. Although this approach has 
the drawback of missing private mutations that have not yet made it to the central Saudi mutation database, the ease of interpreting the results and the avoidance of variants of uncertain significance that are inevitable in a sequencing-based assay are clear advantages. This expanded premarital screening program will build on the existing national premarital screening program for sickle cell disease and thalassemia that has been in effect since 2004 . Currently, an expanded premarital screening program is being piloted on a small number of prospective couples, to collect sufficient data before the official launch of the program in the near future. 


\section{United Kingdom}

The UK comprises four (slightly different) National Health Services (NHS) for England, Scotland, Wales and Northern Ireland. Each of these services is free at the point of delivery and universally accessible to those 'ordinarily' resident in the UK. The National Screening Committee (UK NSC) advises the NHS in the four UK countries about all aspects of population screening and supports implementation of screening programs in general; its database of recommendations sets out over 100 conditions, including recommendations to screen for 30 conditions. Recommendations on whether to screen for a condition are based on internationally recognised criteria and a rigorous evidence review process.

Preconception or prenatal carrier testing for conditions which have a high prevalence in specific (ethnic) populations is available through a variety of clinical services (e.g. hematology, clinical genetics, general practice). Cascade screening in families where a diagnosis has already been made is also available.

Immigration from Commonwealth countries since the middle of the $20^{\text {th }}$ century introduced increased prevalence of hemoglobinopathies: sickle cell disease from West-African countries and the Caribbean, and thalassaemia primarily from the Indian subcontinent. After ad hoc and inconsistent availability of hemoglobinopathy testing since the $1970 \mathrm{~s},{ }^{60}$ a national antenatal screening program for hemoglobinopathies to all pregnant women was recommended by the UK NSC and introduced in the early 2000s through Public Health England. NHS-funded TSD disease carrier screening has been available for people from Jewish ancestry since $1999 .^{61}$

This article is protected by copyright. All rights reserved. 
Several pilot studies for antenatal CF carrier screening were conducted in primary care or maternity hospitals in the $1990 \mathrm{~s},{ }^{62,63}$ but this has not led to a national screening program for the general population. The UK NSC advised against population screening for CF in 2006 since, according to them, it did not meet Wilson and Jungner criteria. ${ }^{64}$ Currently, the NSC is reviewing their recommendation regarding antenatal CF screening. Sickle-cell disease and $\mathrm{CF}$ are both part of the newborn screening program. ${ }^{65}$

The 100,000 Genomes Project (100kGP) recruited NHS patients between 2014 and 2018 and offered a range of different carrier testing as an 'additional finding'. Both parents of children recruited with a rare disease were offered such testing, with the aim of disclosing this as a couple result for autosomal recessive conditions ${ }^{66}$ meaning that individual carrier states would not be disclosed but that the result would only be deemed 'positive' if both parents were found to be a carrier of the same condition. Despite gaining consent for such testing, the pipeline for carrier testing is not yet ready and no results have been disclosed at the time of writing. Although the NHS genomic medicine service has now replaced the $100 \mathrm{kGP}$, it is not entirely clear what carrier testing will be offered when the service goes live later this year.

In an infertility setting, carrier screening for $\mathrm{CF}$ is part of the mandatory screening of potential gamete donors. ${ }^{67}$ Carrier screening for other conditions is offered based on the donor's ethnic background and family history of genetic conditions. A large section of fertility services fall outside the NHS and patients may be offered ECS, but there are no public data on numbers of people offered screening nor for uptake. 


\section{United States of America}

Carrier screening in the USA began in the 1970s, with red cell parameter testing for hemoglobinopathies in African-Americans and enzymatic testing for TSD in AshkenaziJews. While the latter has virtually eliminated TSD in Ashkenazi-Jews, the former was fraught with misconceptions, resentment and low uptake owing to flaws in roll-out and longsimmering cultural mistrust in the community.

Carrier screening at the DNA level first appeared in the USA in the form of targeted allelespecific detection of founder mutations in the Ashkenazi-Jewish population for disorders prevalent in that ethnic group (TSD and others). ${ }^{68}$ The first pan-ethnic carrier screen at the DNA level was for CF, and the USA was the first country to implement nationwide population carrier screening for this disorder, in late 2001, based on recommendations developed by the American College of Medical Genetics (ACMG) and the American College of Obstetricians and Gynecologists (ACOG). The result was a policy to offer CF carrier screening to all couples of reproductive age, using a core mutation panel of 25 (later reduced

to 23) CFTR variants. ${ }^{69,70}$ Almost immediately, however, commercial laboratories took it upon themselves to develop and market screening panels with larger numbers of CFTR mutations, even though this practice had been discouraged in the original recommendations.

Yet this was just a foretaste of what would come when NGS technologies enabled vastly expanded mutation screening, not just for $\mathrm{CF}$ but for hundreds of other recessive disorders as well. Indeed, the same objections could be raised about the inclusion of so many rare and poorly characterized disease genes as had been posited about inclusion of rare and poorly characterized CFTR variants. But the power of NGS was impossible to restrain, especially 
when driven by commercial entities using ever larger disease panels as marketing tools. Ultimately, both ACMG and ACOG felt compelled to revisit their opinions on this matter, and recently both have relaxed their previous objections to such expansion, though couching their positions with such phrases as "may be offered" and "informed decision-making" and minimal carrier frequency requirements for disease inclusion. ${ }^{7,71-73}$ Unfortunately, some of the larger panels include disorders of adult onset, variable severity, low penetrance, or even no symptoms at all. ${ }^{74}$ While there is no question that pan-ethnic ECS identifies more at-risk couples than ethnicity-specific targeted screening and has led to proposals to abandon strict carrier frequency thresholds for inclusion, ${ }^{75,76}$ it comes at a cost of added downstream testing and genetic counseling burden. And to make matters more complicated, the phenomenal popularity of direct-to-consumer genetic testing in the USA means that many patients come to the clinic with dubious carrier results in hand.

Lastly, one cannot ignore "the elephant in the room" surrounding prenatal services in the USA, with many states and the current federal administration constantly attempting to limit or eliminate access to pregnancy termination for any reason. Needless to say, if the option to terminate an affected pregnancy became illegal nationwide, the impetus and market for carrier screening - both standard and expanded - would be dramatically reduced, and the number of babies born with recessive genetic disorders would greatly increase. 


\section{What are the lessons learned from the international experience of RCS?}

This review has shown the enormous variability in how RCS is offered across the globe. This largely relates to geographical variation in carrier frequencies of genetic conditions and local healthcare, financial, cultural and religious factors. Funding of RCS is variable but in many countries funded testing is minimal or only available to those with a high a priori risk. Additionally, access to genetic counseling and the offer of reproductive options also varies significantly. Collectively, this highlights inequity in access to RCS services. The ability to screen for ever increasing numbers of disorders by massively parallel sequencing will identify more at-risk couples but also raises considerable ethical issues about what conditions should be included in such screening and what should be done when variants of uncertain significance are identified. Society and Governments will need to continue to tackle the challenges that such technology raises in making decisions about what, if any, RCS is publicly funded. The "arms race" to offer the biggest panel of genes tested by companies that offer RCS will no doubt continue and will mean that individuals, couples, clinicians and healthcare systems will need to deal with the outcomes of this testing with ever increasing frequency. 


\section{References}

1. Chokoshvili D, Vears D, Borry P. Expanded carrier screening for monogenic disorders: where are we now? Prenat Diagn. 2018;38:59-66.

2. Delatycki M, Laing N, Moore S, et al. Preconception and antenatal carrier screening for genetic conditions: The critical role of general practitioners. Aust J Gen Pract. 2019;48:106-110.

3. Davies SC, Cronin E, Gill M, Greengross P, Hickman M, Normand C. Screening for sickle cell disease and thalassaemia: a systematic review with supplementary research. Health Technol Assess. 2000;4:i-v, 1-99.

4. Kaback MM, Nathan TJ, Greenwald S. Tay-Sachs disease: heterozygote screening and prenatal diagnosis--U.S. experience and world perspective. Prog Clin Biol Res. $1977 ; 18: 13-36$.

5. Watson EK, Mayall E, Chapple J, et al. Screening for carriers of cystic fibrosis through primary health care services. BMJ. 1991;303:504-507.

6. Gason AA, Metcalfe SA, Delatycki MB, et al. Tay Sachs disease carrier screening in schools: educational alternatives and cheekbrush sampling. Genet Med. 2005;7:626632.

7. Gregg AR, Edwards JG. Prenatal genetic carrier screening in the genomic age. Semin Perinatol. 2018;42:303-306.

8. Delatycki MB. The ethics of screening for disease. Pathology. 2012;44:63-68.

9. Henneman L, Borry P, Chokoshvili D, et al. Responsible implementation of expanded carrier screening. Eur J Hum Genet. 2016;24:e1-e12.

This article is protected by copyright. All rights reserved. 
10. van der Hout S, Holtkamp KC, Henneman L, de Wert G, Dondorp WJ. Advantages of expanded universal carrier screening: what is at stake? Eur J Hum Genet. 2016;25:1721.

11. Andermann A, Blancquaert I, Dery V. Genetic screening: a conceptual framework for programmes and policy-making. J Health Serv Res Policy. 2010;15:90-97.

12. Cousens NE, Gaff CL, Metcalfe SA, Delatycki MB. Carrier screening for betathalassaemia: a review of international practice. Eur J Hum Genet. 2010;18:10771083.

13. Cousens NE, Gaff CL, Metcalfe SA, Delatycki MB. "He didn't say that thalassaemia might come up" - beta-thalassaemia carriers' experiences and attitudes. J Community Genet. 2013;4:223-232.

14. Barlow-Stewart K, Burnett L, Proos A, et al. A genetic screening programme for TaySachs disease and cystic fibrosis for Australian Jewish high school students. J Med Genet. 2003;40:e45.

15. Gason AA, Sheffield E, Bankier A, et al. Evaluation of a Tay-Sachs disease screening program. Clin Genet. 2003;63:386-392.

16. Ioannou L, Massie J, Lewis S, et al. Evaluation of a multi-disease carrier screening programme in Ashkenazi Jewish high schools. Clin Genet. 2010;78):21-31.

17. Ioannou L, Massie J, Collins V, McClaren B, Delatycki MB. Population-based genetic screening for cystic fibrosis: attitudes and outcomes. Public Health Genomics. 2010;13:449-456.

18. Massie J, Petrou V, Forbes R, et al. Population-based carrier screening for cystic fibrosis in Victoria: the first three years experience. Aust $N$ Z J Obstet Gynaecol. 2009;49:484-489.

This article is protected by copyright. All rights reserved. 
19. Archibald AD, Smith MJ, Burgess T, et al. Reproductive genetic carrier screening for cystic fibrosis, fragile $\mathrm{X}$ syndrome, and spinal muscular atrophy in Australia: outcomes of 12,000 tests. Genet Med. 2018;20:513-523.

20. Royal Australian and New Zealand College of Obstetricians and Gynaecologists. $\begin{array}{lll}\text { Genetic } & \text { carrier } & 2019 .\end{array}$ https://www.ranzcog.edu.au/RANZCOG_SITE/media/RANZCOG-

MEDIA/Women\%27s\%20Health/Statement\%20and\%20guidelines/Clinical-

Obstetrics/Genetic-carrier-screening(C-Obs-63)New-March-2019_1.pdf?ext=.pdf.

21. Kyrri AR, Kalogerou E, Loizidou D, et al. The changing epidemiology of betathalassemia in the Greek-Cypriot population. Hemoglobin. 2013;37:435-443.

22. Ashiotis T, Zachariadis Z, Sofroniadou K, Loukopoulos D, Stamatoyannopoulos G. Thalassaemia in Cyprus. Br Med J. 1973;2(5857):38-42.

23. Angastiniotis MA, Hadjiminas MG. Prevention of thalassaemia in Cyprus. Lancet. 1981;1(8216):369-371.

24. Alter BP, Modell CB, Fairweather D, et al. Prenatal diagnosis of hemoglobinopathies. A review of 15 cases. $N$ Engl J Med. 1976;295:1437-1443.

25. Angastiniotis M, Kyriakidou S, Hadjiminas M. How thalassaemia was controlled in Cyprus. World Health Forum. 1986;7:291-297.

26. Angastiniotis M, Kyriakidou S, Hadjiminas M. The Cyprus Thalassemia Control Program. Birth Defects Orig Artic Ser. 1988;23:417-432.

27. Cowan RS. Moving up the slippery slope: mandated genetic screening on Cyprus. Am J Med Genet C Semin Med Genet. 2009;151C:95-103.

28. Kolnagou A, Kontoghiorghe CN, Kontoghiorghes GJ. Transition of Thalassaemia and Friedreich ataxia from fatal to chronic diseases. World J Methodol. 2014;4:197-218. 
29. Zamba-Papanicolaou E, Koutsou P, Daiou C, Gaglia E, Georghiou A, Christodoulou K. High frequency of Friedreich's ataxia carriers in the Paphos district of Cyprus. Acta Myol. 2009;28:24-26.

30. Zlotogora J. Genetics and genomic medicine in Israel. Mol Genet Genomic Med. 2014;2:85-94.

31. Zlotogora J, Grotto I, Kaliner E, Gamzu R. The Israeli national population program of genetic carrier screening for reproductive purposes. Genet Med. 2016;18:203-206.

32. Ekstein J, Katzenstein H. The Dor Yeshorim story: community-based carrier screening for Tay-Sachs disease. Adv Genet. 2001;44:297-310.

33. Cao A, Kan YW. The prevention of thalassemia. Cold Spring Harb Perspect Med. 2013;3:a011775.

34. Picci L, Cameran M, Marangon O, et al. A 10-year large-scale cystic fibrosis carrier screening in the Italian population. J Cyst Fibros. 2010;9:29-35.

35. Castellani C, Picci L, Tamanini A, Girardi P, Rizzotti P, Assael BM. Association between carrier screening and incidence of cystic fibrosis. JAMA. 2009;302:25732579.

36. Castellani C, Picci L, Tridello G, et al. Cystic fibrosis carrier screening effects on birth prevalence and newborn screening. Genet Med. 2016;18:145-151.

37. Castellani C, Casati. E. Outcomes of spontaneous application of carrier screening for cystic fibrosis: follow-up of its effects on birth prevalence, neonatal screening and reproductive behavior of carrier couples in The Proceedings of the 16th Italian Convention of Investigators in Cystic Fibrosis. Multidiscip Respir Med. 2019;14:5.

38. Mosconi P, Castellani C, Villani W, Satolli R. Cystic fibrosis: to screen or not to screen? Involving a Citizens' jury in decisions on screening carrier. Health Expect. 2015;18:1956-1967.

This article is protected by copyright. All rights reserved. 
39. Mosconi P, Colombo C, Roberto A, et al. Deciding on cystic fibrosis carrier screening: three citizens' juries and an online survey. Eur J Public Health. 2018;28:973-977.

40. Ainoon $\mathrm{O}$, Alawiyah $\mathrm{A}, \mathrm{Yu} \mathrm{YH}$, et al. Semiquantitative screening test for G6PD deficiency detects severe deficiency but misses a substantial proportion of partiallydeficient females. Southeast Asian J Trop Med Public Health. 2003;34:405-414.

41. Jameela S, Sabirah SO, Babam J, et al. Thalassaemia screening among students in a secondary school in Ampang, Malaysia. Med J Malaysia. 2011;66:522-524.

42. Thong MK, Tan JA, Tan KL, Yap SF. Characterisation of beta-globin gene mutations in Malaysian children: a strategy for the control of beta-thalassaemia in a developing country. J Trop Pediatr. 2005;51:328-333.

43. Yunus ZM, Rahman SA, Choy YS, Keng WT, Ngu LH. Pilot study of newborn screening of inborn error of metabolism using tandem mass spectrometry in Malaysia: outcome and challenges. J Pediatr Endocrinol Metab. 2016;29:1031-1039.

44. Lee JM, Thong MK. Genetic counseling services and development of training programs in Malaysia. J Genet Couns. 2013;22:911-916.

45. Fucharoen S, Winichagoon P. Thalassemia in SouthEast Asia: problems and strategy for prevention and control. Southeast Asian J Trop Med Public Health. 1992;23:647655.

46. Shen Y, Qiu X, Gui B, et al. Implementing comprehensive genetic carrier screening in China-Harnessing the power of genomic medicine for the effective prevention/management of birth defects and rare genetic diseases in China. Pediatr Investig. 2018;2:30-36.

This article is protected by copyright. All rights reserved. 
47. Zhao S, Xiang J, Fan C, et al. Pilot study of expanded carrier screening for 11 recessive diseases in China: results from 10,476 ethnically diverse couples. Eur J Hum Genet. 2019;27:254-262.

48. Bylstra Y, Kuan JL, Lim WK, et al. Population genomics in South East Asia captures unexpectedly high carrier frequency for treatable inherited disorders. Genet Med. 2019;21:207-212.

49. Jans SM, van El CG, Houwaart ES, et al. A case study of haemoglobinopathy screening in the Netherlands: witnessing the past, lessons for the future. Ethn Health. $2012 ; 17: 217-239$.

50. Holtkamp KCA, Lakeman P, Hader H, et al. Experiences of a High-Risk Population with Prenatal Hemoglobinopathy Carrier Screening in a Primary Care Setting: a Qualitative Study. J Genet Couns. 2018;27:635-646.

51. Henneman L, Bramsen I, van Kempen L, et al. Offering preconceptional cystic fibrosis carrier couple screening in the absence of established preconceptional care services. Community Genet. 2003;6:5-13.

52. Lakeman P, Plass AM, Henneman L, Bezemer PD, Cornel MC, ten Kate LP. Preconceptional ancestry-based carrier couple screening for cystic fibrosis and haemoglobinopathies: what determines the intention to participate or not and actual participation? Eur J Hum Genet. 2009;17:999-1009.

53. Holtkamp KCA, Henneman L, Gille JJP, Meijers-Heijboer H, Cornel MC, Lakeman P. Direct-to-consumer carrier screening for cystic fibrosis via a hospital website: a 6year evaluation. J Community Genet. 2019;10:249-257.

54. Mathijssen IB, Henneman L, van Eeten-Nijman JM, et al. Targeted carrier screening for four recessive disorders: high detection rate within a founder population. Eur $J$ Med Genet. 2015;58:123-128.

This article is protected by copyright. All rights reserved. 
55. Schuurmans J, Birnie E, van den Heuvel LM, et al. Feasibility of couple-based expanded carrier screening offered by general practitioners. Eur J Hum Genet. 2019;27:691-700.

56. Plantinga M, Birnie E, Abbott KM, et al. Population-based preconception carrier screening: how potential users from the general population view a test for 50 serious diseases. Eur J Hum Genet. 2016;24:1417-1423.

57. Alkuraya FS. Genetics and genomic medicine in Saudi Arabia. Mol Genet Genomic Med. 2014;2:369-378.

58. Abouelhoda M, Sobahy T, El-Kalioby M, et al. Clinical genomics can facilitate countrywide estimation of autosomal recessive disease burden. Genet Med. 2016;18:1244-1249.

59. Monies D, Abouelhoda M, Assoum M, et al. Lessons Learned from Large-Scale, First-Tier Clinical Exome Sequencing in a Highly Consanguineous Population. Am J Hum Genet. 2019;104:1182-1201.

60. Zeuner D, Ades AE, Karnon J, Brown J, Dezateux C, Anionwu EN. Antenatal and neonatal haemoglobinopathy screening in the UK: review and economic analysis. Health Technol Assess. 1999;3:i-v, 1-186.

61. Burton H, Levene S, Alberg C, Stewart A. Tay Sachs Disease carrier screening in the Ashkenazi Jewish population: A needs assessment and review of current services. 2009; http://www.phgfoundation.org/documents/195_1242810652.pdf.

62. Bekker H, Modell M, Denniss G, et al. Uptake of cystic fibrosis testing in primary care: supply push or demand pull? BMJ. 1993;306(6892):1584-1586.

63. Mennie ME, Gilfillan A, Compton M, et al. Prenatal screening for cystic fibrosis. Lancet. 1992;340(8813):214-216. 
64. Wilson JM, Jungner YG. Principles and practice of mass screening for disease. Bol Oficina Sanit Panam. 1968;65:281-393.

65. England PH. Guidance: Newborn Blood Spot Screening: Programme Overview. 2018; $\quad$ https://www.gov.uk/guidance/newborn-blood-spot-screening-programmeoverview\#screening-tests. Accessed 12 April 2019.

66. England G. Genomics England: The Journey to 100.000 genomes. 2018; https://www.genomicsengland.co.uk/the-journey-to- 100000-genomes/. Accessed 12 April 2019.

67. Association of Biomedical A, Association of Clinical E, British Andrology S, British Fertility S, Royal College of O, Gynaecologists. UK guidelines for the medical and laboratory screening of sperm, egg and embryo donors (2008). Hum Fertil (Camb). 2008;11:201-210.

68. Gross SJ, Pletcher BA, Monaghan KG, Professional P, Guidelines C. Carrier screening in individuals of Ashkenazi Jewish descent. Genet Med. 2008;10:54-56.

69. Grody WW, Cutting GR, Klinger KW, et al. Laboratory standards and guidelines for population-based cystic fibrosis carrier screening. Genet Med. 2001;3:149-154.

70. Watson MS, Cutting GR, Desnick RJ, et al. Cystic fibrosis population carrier screening: 2004 revision of American College of Medical Genetics mutation panel. Genet Med. 2004;6:387-391.

71. Committee on Genetics. Committee Opinion No. 690: Carrier Screening in the Age of Genomic Medicine. Obstet Gynecol. 2017;129:e35-e40.

72. Edwards JG, Feldman G, Goldberg J, et al. Expanded carrier screening in reproductive medicine-points to consider: a joint statement of the American College of Medical Genetics and Genomics, American College of Obstetricians and 
Gynecologists, National Society of Genetic Counselors, Perinatal Quality Foundation, and Society for Maternal-Fetal Medicine. Obstet Gynecol. 2015;125:653-662.

73. Stevens B, Krstic N, Jones M, Murphy L, Hoskovec J. Finding Middle Ground in Constructing a Clinically Useful Expanded Carrier Screening Panel. Obstet Gynecol. 2017;130:279-284.

74. Grody WW. Where to Draw the Boundaries for Prenatal Carrier Screening. JAMA. 2016;316:717-719.

75. Ben-Shachar R, Svenson A, Goldberg JD, Muzzey D. A data-driven evaluation of the size and content of expanded carrier screening panels. Genet Med. 2019;21:19311939.

76. Peyser A, Singer T, Mullin C, et al. Comparing ethnicity-based and expanded carrier screening methods at a single fertility center reveals significant differences in carrier rates and carrier couple rates. Genet Med. 2019;21:1400-1406.

This article is protected by copyright. All rights reserved. 
Table 1- Reproductive carrier screening and reproductive options in the nine different countries/regions

\begin{tabular}{|c|c|c|c|}
\hline & Screening available & $\begin{array}{l}\text { Termination of } \\
\text { pregnancy for } \\
\text { genetic disorders }\end{array}$ & $\begin{array}{l}\text { Preimplantation } \\
\text { genetic testing- } \\
\text { monogenic } \\
\text { disorders }\end{array}$ \\
\hline Australia & $\begin{array}{l}\text { Hemoglobinopathy screening } \\
\text { Government funded. Other RCS } \\
\text { in the absence of family history } \\
\text { is user pays. }\end{array}$ & $\begin{array}{l}\text { Legal and } \\
\text { Government } \\
\text { funded }\end{array}$ & $\begin{array}{l}\text { Available, } \\
\text { partially } \\
\text { Government } \\
\text { funded, partially } \\
\text { user pays }\end{array}$ \\
\hline Cyprus & $\begin{array}{l}\text { Hemoglobinopathy and } \\
\text { Friedreich ataxia screening are } \\
\text { Government funded. }\end{array}$ & $\begin{array}{l}\text { Legal and } \\
\text { Government } \\
\text { funded }\end{array}$ & $\begin{array}{l}\text { Available, } \\
\text { partially } \\
\text { Government } \\
\text { funded, partially } \\
\text { user pays }\end{array}$ \\
\hline Israel & $\begin{array}{l}\text { Screening available for all } \\
\text { severe diseases with an } \\
\text { incidence higher than } 1 \text { in } \\
15,000 \text { and is Government } \\
\text { funded }\end{array}$ & $\begin{array}{l}\text { Legal and funded } \\
\text { by National } \\
\text { Health insurance }\end{array}$ & $\begin{array}{l}\text { Available and } \\
\text { funded by } \\
\text { National Health } \\
\text { insurance for a } \\
\text { maximum of two } \\
\text { children }\end{array}$ \\
\hline Italy & $\begin{array}{l}\text { Hemoglobinopathy screening } \\
\text { Government funded. CF }\end{array}$ & $\begin{array}{l}\text { Legal and } \\
\text { Government }\end{array}$ & $\begin{array}{l}\text { Available. } \\
\text { Government }\end{array}$ \\
\hline
\end{tabular}




\begin{tabular}{|c|c|c|c|}
\hline & $\begin{array}{l}\text { screening in the absence of } \\
\text { family history on a regional } \\
\text { basis: in some areas regional } \\
\text { Government funded with a } \\
\text { nominal fee, in other areas user } \\
\text { pays. }\end{array}$ & funded & $\begin{array}{l}\text { funded in one } \\
\text { Institution, user } \\
\text { pays in several } \\
\text { others. }\end{array}$ \\
\hline Malaysia & $\begin{array}{l}\text { Hemoglobinopathy screening } \\
\text { Government funded. Other RCS } \\
\text { is user pays. }\end{array}$ & $\begin{array}{l}\text { Legal and } \\
\text { Government } \\
\text { funded at public } \\
\text { hospitals if } \\
\text { maternal health is } \\
\text { at risk. }\end{array}$ & $\begin{array}{l}\text { Available in } \\
\text { selected private } \\
\text { healthcare } \\
\text { facilities and is } \\
\text { user pays. }\end{array}$ \\
\hline Netherlands & $\begin{array}{l}\text { Hemoglobinopathy screening by } \\
\text { HPLC/electrophoresis is } \\
\text { reimbursed. Two hospitals offer } \\
\text { expanded RCS (50-70 } \\
\text { disorders) that is reimbursed in } \\
\text { high-risk couples }{ }^{\dagger} \text { but is user } \\
\text { pays in the absence of family } \\
\text { history or other high-risk } \\
\text { indication. One hospital offers } \\
\text { RCS (>1900 genes) for } \\
\text { consanguineous couples that is } \\
\text { reimbursed }{ }^{\dagger} \text {. Screening in one } \\
\text { specific Dutch founder }\end{array}$ & $\begin{array}{l}\text { Legal up to } 24 \\
\text { weeks pregnancy } \\
\text { and Government } \\
\text { funded. }\end{array}$ & $\begin{array}{l}\text { Available, three } \\
\text { cycles } \\
\text { Government } \\
\text { funded }^{\dagger} \text {. }\end{array}$ \\
\hline
\end{tabular}




\begin{tabular}{|c|c|c|c|}
\hline & population is reimbursed ${ }^{\dagger}$. & & \\
\hline Saudi Arabia & $\begin{array}{l}\text { Hemoglobinopathy screening } \\
\text { Government-mandated and } \\
\text { funded. Targeted screening for } \\
\text { familial mutations optional and } \\
\text { Government-funded. Optional } \\
\text { expanded carrier screening soon } \\
\text { to be launched and } \\
\text { Government-funded. }\end{array}$ & $\begin{array}{l}\text { Legal and } \\
\text { Government } \\
\text { funded for strict } \\
\text { indications and } \\
\text { with a strict upper } \\
\text { gestation limit. }\end{array}$ & $\begin{array}{l}\text { Available and } \\
\text { Government } \\
\text { funded. }\end{array}$ \\
\hline UK & $\begin{array}{l}\text { Hemoglobinopathy andTay- } \\
\text { Sachs disease screening state- } \\
\text { funded (and offered as } \\
\text { population screen depending on } \\
\text { ancestry). Other screening is } \\
\text { state funded if family history of } \\
\text { a condition. User pays for } \\
\text { testing outside of National } \\
\text { Health Service (NHS) eg } \\
\text { fertility clinic }\end{array}$ & $\begin{array}{l}\text { State-funded and } \\
\text { legal but very } \\
\text { restricted in } \\
\text { Northern Ireland }\end{array}$ & $\begin{array}{l}\text { Available for } \\
\text { conditions } \\
\text { licenced by } \\
\text { Human } \\
\text { Fertilisation and } \\
\text { Embryology } \\
\text { Authority, } \\
\text { partially } \\
\text { Government } \\
\text { funded, partially } \\
\text { user pays }\end{array}$ \\
\hline USA & $\begin{array}{l}\text { Mix of government, private } \\
\text { insurance, and self-pay }\end{array}$ & $\begin{array}{l}\text { Varies widely by } \\
\text { state; where legal } \\
\text { and available, } \\
\text { government or } \\
\text { insurance funded }\end{array}$ & $\begin{array}{l}\text { Varies by state; } \\
\text { some pay (in } \\
\text { part) for PGT-M } \\
\text { but not IVF; } \\
\text { many procedures }\end{array}$ \\
\hline
\end{tabular}




\begin{tabular}{|l|l|l|l|}
\hline & with prior & are self-pay \\
authorization; & other states have & \\
severe legal & restrictions and no \\
financial & coverage; no \\
& federal \\
& Government \\
& funding under the \\
& Hyde Amendment \\
\hline
\end{tabular}

${ }^{\dagger}$ Reimbursement by health insurance. The mandatory insurance deductible in 2019 is $€ 385$ per calendar year. 


\section{University Library}

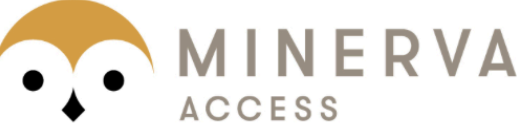

A gateway to Melbourne's research publications

Minerva Access is the Institutional Repository of The University of Melbourne

\section{Author/s:}

Delatycki, MB;Alkuraya, F;Archibald, A;Castellani, C;Cornel, M;Grody, WW;Henneman, L;loannides, AS;Kirk, E;Laing, N;Lucassen, A;Massie, J;Schuurmans, J;Thong, M-K;van Langen, l;Zlotogora, J

Title:

International perspectives on the implementation of reproductive carrier screening

Date:

2019-11-29

\section{Citation:}

Delatycki, M. B., Alkuraya, F., Archibald, A., Castellani, C., Cornel, M., Grody, W. W., Henneman, L., Ioannides, A. S., Kirk, E., Laing, N., Lucassen, A., Massie, J., Schuurmans, J., Thong, M. -K., van Langen, I. \& Zlotogora, J. (2019). International perspectives on the implementation of reproductive carrier screening. PRENATAL DIAGNOSIS, 40 (3), pp.301-310. https://doi.org/10.1002/pd.5611.

Persistent Link:

http://hdl.handle.net/11343/286676 